Research, part of a Special Feature on Effects of Roads and Traffic on Wildlife Populations and Landscape Function

\title{
Road Impacts on Abundance, Call Traits, and Body Size of Rainforest Frogs in Northeast Australia
}

\author{
$\underline{\text { Conrad J. Hoskin }}^{1}$ and Miriam W. Goosem ${ }^{2}$
}

\begin{abstract}
Frogs are potentially sensitive indicators of road impacts, with studies indicating particular susceptibility to road mortality. Calling, i.e., breeding, behavior could also be affected by traffic noise. We investigated effects on frog abundance and calling behavior where a busy highway crosses rainforest stream breeding habitat in northeast Australia. Frog abundance was repeatedly surveyed along five stream transects during a summer breeding season. Abundance of two species, Litoria rheocola and Austrochaperina pluvialis, increased significantly with perpendicular distance from the road along two transects. No trends in abundance were detected for A. pluvialis on two other transects where it was common, or for Litoria serrata on one transect where abundance was sufficient for analysis. Both species with lowered abundance near the road, L. rheocola and A. pluvialis, are rare in road kill statistics along this highway, suggesting road mortality is not the cause of reduced frog abundance near the road. We postulate that lowered abundance may reflect traffic noise effects. We analyzed calls of the International Union for Conservation of Nature endangered species $L$. rheocola along the one stream transect on which it was common. We found significant trends in two call traits over a very fine scale: both call rate and dominant frequency were significantly higher closer to the road. Furthermore, males were significantly smaller closer to the road. These call and body size trends most likely reflect road impacts, but resolving these is complicated by correlations between traits. Potential mechanisms, effects on fitness, and management recommendations to mitigate the impacts of roads on frogs are outlined.
\end{abstract}

Key Words: call frequency; call masking; Litoria rheocola; road kill; stream; traffic noise

\section{INTRODUCTION}

Roads are a ubiquitous and expanding anthropogenic feature of the modern landscape, affecting not only urban areas but also remote and protected areas (Forman et al. 2003, Laurance et al. 2008). Although studies have examined road impacts in tropical rainforests (Goosem 2007, Laurance et al. 2009), effects on rainforest frogs have received little attention. Roads in temperate habitats can reduce amphibian species richness and abundance (Fahrig et al. 1995, Trenham et al. 2003, Pellet et al. 2004a, 2004b, Parris 2006, Eigenbrod et al. 2008, Fahrig and Rytwinski 2009), with road mortality believed to be the primary impact (Fahrig et al. 1995, Fahrig and Rytwinski 2009). Of particular interest is the potential effect of traffic noise on frogs. Increasingly, noise produced by human activities has become the dominant sound in many environments (Brumm 2006, Warren et al. 2006). In particular, traffic noise has become a pervasive low frequency sound, not just in urban environments but also where roads pass through natural environments. Calling is the primary mechanism of species recognition, mate choice, and male-male interaction in frogs (Gerhardt and Huber 2002), and therefore if traffic noise alters calling behaviour, it may in turn affect breeding success and fitness.

Masking interference from traffic noise has been shown to significantly affect birds and drive local adaptation via louder calls (Brumm 2004), higher pitched calls (Slabbekoorn and Peet 2003, Slabbekoorn and Boer-Visser 2006, Parris and Schneider 2009), shorter calls (Slabbekoorn and Boer-Visser 2006), more calls, i.e., a faster call rate (Slabbekoorn and Boer-Visser 2006), and call timing to avoid traffic peaks (Fuller et al. 2007).

\footnotetext{
${ }^{1}$ Australian National University, Canberra, ACT, Australia, ${ }^{2}$ James Cook University, Cairns, Queensland, Australia
} 
Few such studies have been conducted on frogs. Frogs may be particularly susceptible to traffic noise effects because calling is key to their reproductive biology and the relatively low frequency of frog calls increases the potential for masking by traffic noise. Frogs calling in traffic noise have been found to call at higher frequency (Parris et al. 2009), and to alter call rate, i.e., a decrease in three species and increase in one (Sun and Narins 2005). Road noise has also been shown to reduce the ability of females to locate calls (Bee and Swanson 2007), and has been implicated in patterns of reduced species richness and abundance near a highway (Eigenbrod et al. 2009).

Here we studied road impacts on rainforest frogs in the Wet Tropics World Heritage Area (WTWHA) of northeast Australia. This large area of protected habitat is interspersed with other land-uses and heavily bisected by busy roads. Road impact research in the WTWHA has primarily focused on mammals and birds (e.g., Goosem 2000a, b, 2001, Goosem et al. 2006, Kofron and Chapman 2006, Wilson et al. 2007, Laurance et al. 2009). In contrast, the diverse and threatened frog fauna has received little attention, despite potentially high susceptibility to road impacts. We focused on stream-breeding rainforest frogs for several reasons. First, Australian stream-breeding species generally have low frequency calls relative to their pool-breeding counterparts (Hoskin et al. 2009), potentially increasing threats posed by the low dominant frequency of traffic noise (Dawe and Goosem 2008). Second, stream-breeding species are suited to road impact studies because their spatial distribution and breeding habitat is highly defined and relatively linear. Third, stream-breeding frog species of the WTWHA have suffered recent declines, with seven species declining dramatically, three probably to extinction (Richards et al. 1993, Hoskin and Hero 2008). These declines in apparently pristine upland rainforest appear largely attributable to chytridiomycosis disease (Berger et al. 1998). Populations of some of these species have persisted in lowland and midaltitude rainforest, areas most affected by human use. Many of the residual populations are small and highly localized, and are therefore vulnerable to additional localized threats such as road impacts.

We assessed whether a highway affects the abundance or calling behaviour, and hence potential breeding success, of rainforest stream frogs. First, we surveyed frog abundance in streams crossed by the road. We predicted that frogs would occur at lower density in stream habitat near the road because of either road mortality or disturbance from traffic noise. Second, we analyzed mating calls of an endangered species, Litoria rheocola, on one of these transects to test for variation in integral calling traits with proximity to the road. In this regard we had two predictions: (1) that frogs would call at higher frequencies near the road to minimize acoustic overlap with low frequency traffic noise, and (2) that call rate would be lower near the road due to suppression of calling activity during traffic noise. We also measured body size of recorded individuals to assess correlations with call traits that may complicate interpretations. For example, call frequency is dependent on body size in frogs (Gerhardt and Huber 2002, Hoskin et al. 2009), and, in turn, body size trends may be indicative of road impacts such as road kill. We discuss the potential impacts of roads on frogs and outline management recommendations to mitigate them.

\section{METHODS}

\section{Study sites and traffic volume}

Study sites were situated on the Kuranda Range section of the Kennedy Highway, about $15 \mathrm{~km}$ north of Cairns, northeast Queensland (Fig. 1, Appendix 1). The mainly two-lane highway traverses tropical rainforest and varies between 12 and $28 \mathrm{~m}$ in clearing width, i.e., rainforest edge to rainforest edge, and 8-12 $\mathrm{m}$ in sealed road surface width. The road carries a heavy traffic volume, with the most recent counts ranging from 6,400-6,800 vehicles per day, January-February 2006, to a maximum monthly traffic level in the peak of the tourist season of about 7,500 vehicles/day, in August 2005 (Queensland Department of Main Roads [QDMR], unpublished data). The winding nature of the road results in traffic speeds ranging between 45 and 80 $\mathrm{km} \mathrm{hr}^{-1}$, with the legislated speed limit of $80 \mathrm{~km} \mathrm{~h}^{-1}$ seldom exceeded.

\section{Road impacts on frog abundance}

\section{Stream transects}

Five replicate transects were surveyed, covering all permanent flowing streams crossed by the highway (Fig. 1, Appendix 1). Transects started at the road 
Fig. 1. Map of the study region, showing location of the stream and road transects. Stream transects are marked by thickened grey stream and numbered in grey as: (1) upstream Streets Creek, (2) downstream Streets Creek, (3) upper Avondale Creek, (4) lower Avondale Creek upstream, (5) lower Avondale Creek downstream. Road transects are marked as open sections of road and numbered in black as: (1) upstream Streets Creek, (2) downstream Streets Creek, (3) upper Avondale Creek, (4) lower Avondale Creek.

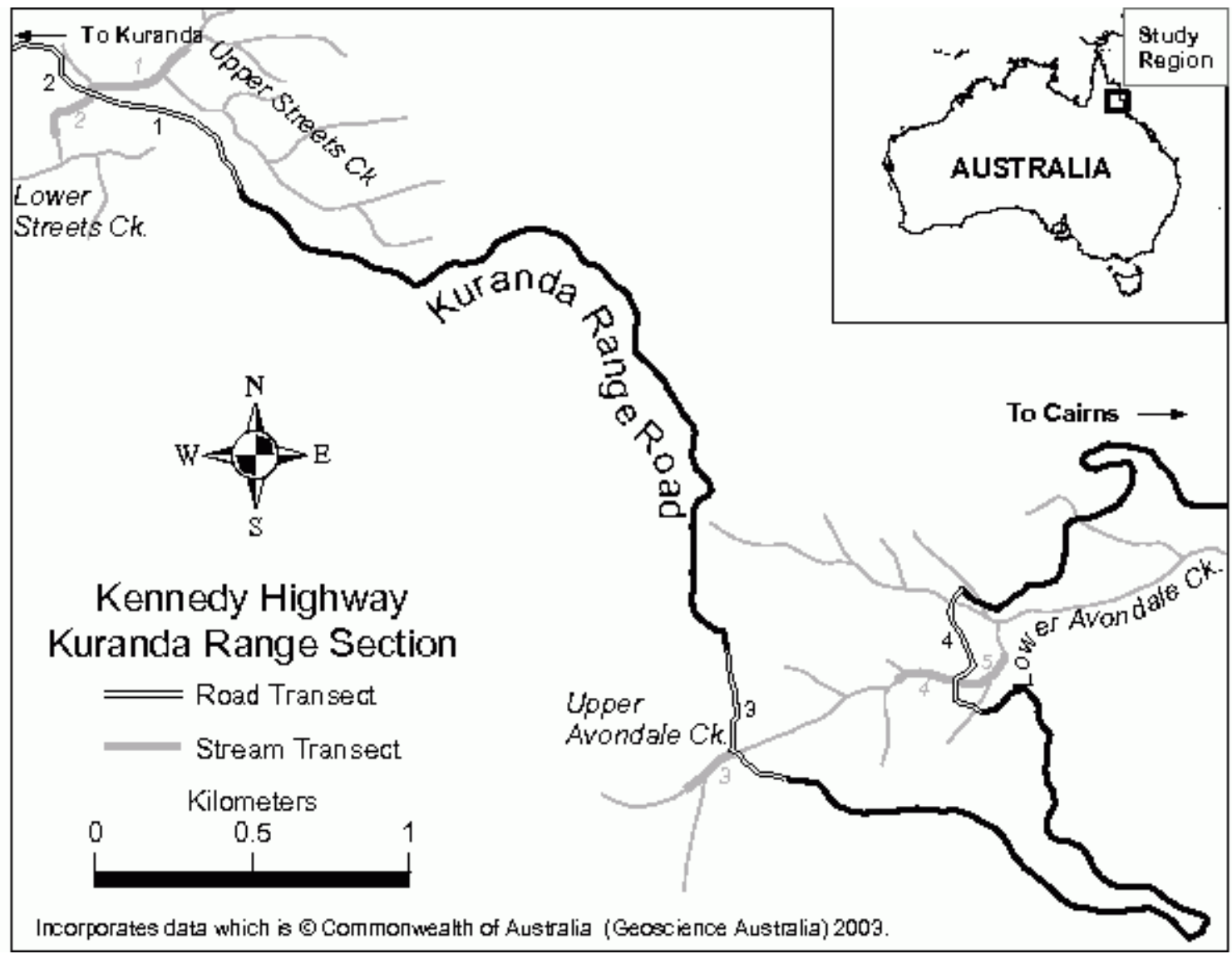

crossing and followed the stream path through rainforest for a sufficient distance to reach $100 \mathrm{~m}$ perpendicular from the road where it was considered that the effects of road noise on frog calling behavior was likely to be low. Transect lengths differed due to variation in the orientation of the streams, with $100 \mathrm{~m}$ perpendicular distance attained rapidly on streams approximately perpendicular to the road, but over longer distances on other transects (Fig. 1, Appendix 1).
On each transect, distance was marked with flagging tape every $5 \mathrm{~m}$. We measured the orientation of each $5 \mathrm{~m}$ stream section and plotted the stream path of each transect on an accurate map of the road route, provided by QDMR. From this we calculated perpendicular distance to the nearest road edge for every $5 \mathrm{~m}$ point along each stream transect. Stream habitat was characterized for every $5 \mathrm{~m}$ section according to the following broad habitat types: cascades, i.e., rushing flow dropping over or between rocks; riffles, i.e., shallow, generally 
dispersed flow over gravel or small rocks; and pools, i.e., deeper sections of stream where flow appears minimal.

\section{Frog stream transect surveys}

Transects were surveyed once per week for a total of six times between 22 January and 28 February 2007, between 19:00 hours and midnight. Survey techniques were consistent across all visits, including always involving just one person $(\mathrm{CJH})$ detecting frogs. Conditions during the survey period were ideal for frog breeding activity, being warm $\left(23-27^{\circ} \mathrm{C}\right)$, humid, and with periodic heavy rain. Frogs were detected by calls and/or sight. Most frogs detected were mature males calling along the stream. Females and subadults of these species generally live away from streams (Hoskin and Hero 2008). Only frogs within $5 \mathrm{~m}$ of the stream center were included, estimated using markers at that distance. Location to the nearest $5 \mathrm{~m}$ marker on the stream transect was recorded, along with species and sex.

Count data from each survey were pooled in $5 \mathrm{~m}$ stream transect sections for each species and converted to perpendicular distances from the road, to the nearest $5 \mathrm{~m}$. This data was then grouped into $20 \mathrm{~m}$ distances from the road, i.e., 1-20, 21-40, $41-60,61-80,81-100 \mathrm{~m}$, to overcome vagaries of habitat variation and incorporate sufficient individuals in each group to accurately estimate density change with distance. Abundance was standardized by dividing the count for each $20 \mathrm{~m}$ distance group by the length of stream transect in that distance group, then averaged for each of the six replicate transect surveys due to likely nonindependence of frogs across replicates. Following normality testing, average standardized frog abundance was analyzed against distance to the road in linear regressions. Regressions were only conducted for species and total frog counts averaging approximately 10 or more individuals per $100 \mathrm{~m}$ (numbers in bold in Table 1). Abundances less than this were deemed too low to assess road effects.

\section{Frog road mortality transect surveys}

Road mortality was surveyed between May 2005 and April 2006. Four highway transects were surveyed, each $500 \mathrm{~m}$ in length, and each bisecting or running adjacent to one of the frog survey streams
(Fig 1). Road mortality was sampled weekly by walking along each transect in either direction between dawn and about 10:00 hours. All road kill was located on the road surface to within $2 \mathrm{~m}$ accuracy, according to a grid system using road posts and culverts, then removed from the road surface. Each specimen was either identified in situ or collected for microscopic identification.

\section{Road impacts on call traits and body size}

\section{Frog call recording}

Litoria rheocola were targeted for call recording on the upstream Streets Creek transect, which extended to $180 \mathrm{~m}$ perpendicular distance from the road. Litoria rheocola was calling well during the survey period and the orientation of this transect, and the abundance of males along its length enabled recordings to be obtained across a range of distances from the road. Other species were not recorded because they only called during rain, e.g., Austrochaperina pluvialis, were calling poorly during the survey period, e.g., Litoria serrata, or were too rare. Calls were recorded using a Marantz digital recorder and a Sennheiser microphone. The microphone was held approximately $1 \mathrm{~m}$ from the male and an approximately 1 minute string of consecutive calls was recorded. Air temperature and transect position were recorded. The male was then captured in a small plastic bag, measured (snoutvent-length, SVL) using vernier calipers, and then released at the point of capture.

\section{Call measurements}

Four integral call traits were measured: call duration, i.e., length of call from beginning of the first pulse to end of the last pulse; pulse rate, i.e., the number of pulses per second across entire call; dominant frequency, i.e., frequency at which the call is of greatest intensity; and call rate, i.e., time between end of one call and beginning of next call. These call traits have previously been shown to be informative measures of call variation (e.g., Gerhardt and Huber 2002, Hoskin 2004, Hoskin et al. 2005, 2009). Four consecutive calls were measured for each individual using the software Canary version 1.2.1, and the values for each trait were averaged across these to give the data for that individual. 
Table 1. Frog abundance on the stream transects. All transects were surveyed six times. Table shows the conservation status of the species; the total number of records for each species across all transects; and the average number of individuals of each species per $100 \mathrm{~m}$ on each transect (a standardized measure of abundance). Bolding shows species (or total frogs) recorded at an abundance of approximately 10 individuals or more per $100 \mathrm{~m}$. Status is the Australian EPBC status; categories here are E (Endangered) and LC (Least Concern). Two species are recently described (marked with asterisk) and are common and best considered LC. Litoria serrata was formerly included within L. genimaculata (Richards et al. 2010).

\begin{tabular}{|c|c|c|c|c|c|c|c|}
\hline \multirow[t]{2}{*}{ Species } & \multirow[t]{2}{*}{ Status } & \multirow{2}{*}{$\begin{array}{l}\text { Total } \\
\text { No. }\end{array}$} & $\begin{array}{c}\text { lower } \\
\text { Avondale } \mathrm{Ck} \\
\text { downstream }\end{array}$ & $\begin{array}{c}\text { lower } \\
\text { Avondale } \mathrm{Ck}, \\
\text { upstream }\end{array}$ & $\begin{array}{c}\text { upper } \\
\text { Avondale Ck, } \\
\text { upstream }\end{array}$ & $\begin{array}{l}\text { Streets Ck, } \\
\text { downstream }\end{array}$ & $\begin{array}{l}\text { Streets Ck, } \\
\text { upstream }\end{array}$ \\
\hline & & & No./ 100 m & No./ 100 m & No./ 100 m & No./ $100 \mathrm{~m}$ & No./ $100 \mathrm{~m}$ \\
\hline Litoria serrata & $\mathrm{LC}$ & 295 & 1.4 & 3.1 & 14.9 & 3.3 & 4.6 \\
\hline Litoria rheocola & $\mathrm{E}$ & 189 & 0 & 0 & 0 & 0.2 & 9.6 \\
\hline Litoria jungguy & $*$ & 13 & 0.2 & 0.1 & 0 & 0.7 & 0.1 \\
\hline Litoria infrafrenata & $\mathrm{LC}$ & 2 & 0.1 & 0.1 & 0 & 0 & 0 \\
\hline Litoria xanthomera & $\mathrm{LC}$ & 1 & 0 & 0.1 & 0 & 0 & 0 \\
\hline Mixophyes coggeri & $*$ & 9 & 0 & 0 & 0 & 0.2 & 0.4 \\
\hline $\begin{array}{l}\text { Austrochaperina } \\
\text { pluvialis }\end{array}$ & $\mathrm{LC}$ & 485 & 0.2 & 0.1 & 9.9 & 15.7 & 11.3 \\
\hline Cophixalus ornatus & $\mathrm{LC}$ & 54 & 0 & 0 & 1.3 & 0.8 & 1.8 \\
\hline Bufo marinus & $\mathrm{LC}$ & 8 & 0.3 & 0.2 & 0 & 0.1 & 0.1 \\
\hline TOTAL FROGS & & 1056 & 2.2 & 3.7 & 26.1 & 21 & 27.9 \\
\hline
\end{tabular}

\section{Analysis}

We aimed to analyze variation in call traits and body size against perpendicular distance to the road, and to examine complicating relationships between these traits. Analyses were performed in SPSS version 15.0. Air temperature variation, which can affect call traits (Gerhardt and Huber 2002), was negligible across the recordings $\left(1^{\circ} \mathrm{C}\right)$. All traits were tested for normality using both KolmogorovSmirnov and Shapiro-Wilks tests, and, where required, transformations were applied to normalize the data. Linear regression was used to test the relationship between each call trait and perpendicular distance from the road. Analyses were conducted at two scales: (1) data from across the full range of perpendicular distance from the road (15-180 m), and (2) only data for males within
$55 \mathrm{~m}$ perpendicular distance from the road. These two scales were examined because road noise effects were initially expected up to $100 \mathrm{~m}$ into the forest, but this estimate was subsequently revised based on the degree to which stream noise masks traffic noise. Nocturnal traffic noise declines abruptly along the stream, halving by $60 \mathrm{~m}$ perpendicular distance from the road (M. Goosem, unpublished data). Therefore, data up to $55 \mathrm{~m}$ distance was chosen for the second scale, incorporating a large number of males $(53 \%)$ and marking a break in the data to the next male at 78 $\mathrm{m}$. Linear regression was also used to test the relationship between frog size (SVL) and distance from the road, and relationships between each call trait and SVL. Relationships between call traits were tested using Pearson Correlations tests. 


\section{RESULTS}

\section{Road impacts on frog abundance}

The abundance of individual species and all frogs combined was too low on both lower Avondale transects to analyze abundance relationships against distance from the road (Table 1). On the upper Avondale transect, two frog species, A. pluvialis and L. serrata, were sufficiently common to be analyzed (Table 1). Linear regressions revealed no significant relationship between abundance and distance from the road for either species (A. pluvialis, $\beta=-0.051$, $\mathrm{F}_{133}=0.01, \mathrm{P}=0.935 ;$ Fig. $2 \mathrm{~A} ;$ L serrata, $\beta=0.080$, $\mathrm{F}_{1,3}=0.02, \mathrm{P}=0.899$; Fig. $2 \mathrm{~B}$ ) or for all frogs combined $\left(\beta=0.195, F_{1,3}=0.12, P=0.735\right)$.

Frog abundance was high on the downstream Streets Creek transect due to the abundance of A. pluvialis, which was recorded at five times the abundance of the next most common species (Table 1). There was a significant positive relationship between $A$. pluvialis abundance and distance from the road $(\beta$ $=0.931, \mathrm{~F}_{1,3}=19.57, \mathrm{P}=0.021 ;$ Fig. $2 \mathrm{C}$ ), and also between total frog abundance (primarily $A$. pluvialis) and distance from the $\operatorname{road}(\beta=0.937$, $\left.\mathrm{F}_{1,3}=21.65, \mathrm{P}=0.019\right)$.

Frog abundance was also high on the upstream Streets Creek transect, with A. pluvialis and the endangered species $L$. rheocola both common (Table 1). There was a significant positive relationship between $L$. rheocola abundance and distance from the road $\left(\beta=0.921, \mathrm{~F}_{1,3}=16.88, \mathrm{P}=\right.$ 0.026 ; Fig. 2D). In contrast, there was no relationship between abundance and distance from the road for $A$. pluvialis $\left(\beta=-0.294, \mathrm{~F}_{1,3}=0.28, \mathrm{P}\right.$ $=0.631$; Fig. $2 \mathrm{E})$ or all frogs combined $(\beta=0.456$, $\left.\mathrm{F}_{1,3}=0.79, \mathrm{P}=0.440\right)$. Litoria rheocola occurred primarily around riffle habitat. Therefore, we assessed the proportion of this habitat type against perpendicular distance to the road to examine whether habitat availability explained the density pattern seen in L. rheocola. Habitat suitability, i.e., proportion of riffle habitat per stream length in each $20 \mathrm{~m}$ distance perpendicular to the road, did not appear to explain the pattern; in fact the highest proportion of suitable habitat was in the $20 \mathrm{~m}$ section closest to the road $(20 \mathrm{~m}, 75 \% ; 40 \mathrm{~m}, 50 \% ; 60 \mathrm{~m}$, $61 \% ; 80 \mathrm{~m}, 38 \% ; 100 \mathrm{~m}, 60 \%)$. Habitat suitability could not be assessed for the A. pluvialis density pattern on the downstream Streets Creek transect because the habitat requirements of this terrestrial breeding species are insufficiently known.
Road mortality of frog species commonly found on the stream transects

Table 2 shows the relative abundance of each frog species on the neighboring road kill and stream transects. Notably, no road mortality was recorded for the most common species found in the stream transect surveys, A. pluvialis. Only two L. rheocola were killed near the Streets Creek transects, despite the abundance of the species on the upstream transect. Similar mortality levels were recorded in weekly surveys during 38 months between 1989 and 1992: only five A. pluvialis and no L. rheocola (Goosem 2000a). In contrast, Litoria serrata suffered road mortality approximately proportional to its relative abundance on the Streets Creek stream transects but was relatively rare in road kill statistics near the Avondale Creek transects. Two species, $L$. xanthomera and L. jungguy, suffered noticeably high mortality relative to their rarity on the stream transects.

\section{Road impacts on call traits and body size}

Call and body size variation up to $180 \mathrm{~m}$ perpendicular distance to the road

Call data were obtained for $41 \mathrm{~L}$. rheocola males from the upstream Streets Creek transect, across the range of distances from the road. Data for call duration, pulse rate, dominant frequency, and SVL were normally distributed, but log transformations were required to normalize the call rate and distance to road data. Regressions of individual traits against perpendicular distance to the road revealed no significant relationship for dominant frequency $(\beta$ $\left.=-0.219, \mathrm{~F}_{1,38}=1.917, \mathrm{P}=0.174\right)$, call duration $(\beta$ $\left.=0.273, \mathrm{~F}_{1,36}=2.907, \mathrm{P}=0.097\right)$, or pulse rate $(\beta$ $\left.=-0.256, \mathrm{~F}_{1,36}=2.514, \mathrm{P}=0.122\right)$. There was, however, a significant negative relationship between call rate and distance to the road $(\beta$ $\left.=-0.366, \mathrm{~F}_{1.36}=5.573, \mathrm{P}=0.024\right)$, with frogs near the road calling more frequently (Fig. 3A). There was also a highly significant positive relationship between male size and distance to the $\operatorname{road}(\beta=$ $\left.0.515, \mathrm{~F}_{1,37}=13.36, \mathrm{P}=0.001\right)$, with males near the road being significantly smaller than those further from the road (Fig. 3B). 
Fig. 2. Average abundance of species versus perpendicular distance to the road. (A) A. pluvialis on the upper Avondale Creek transect, (B) L. serrata on the upper Avondale Creek transect, (C) A. pluvialis on the downstream Streets Creek transect, (D) L. rheocola on the upstream Streets Creek transect, (E) $A$. pluvialis on the upstream Streets Creek transect.
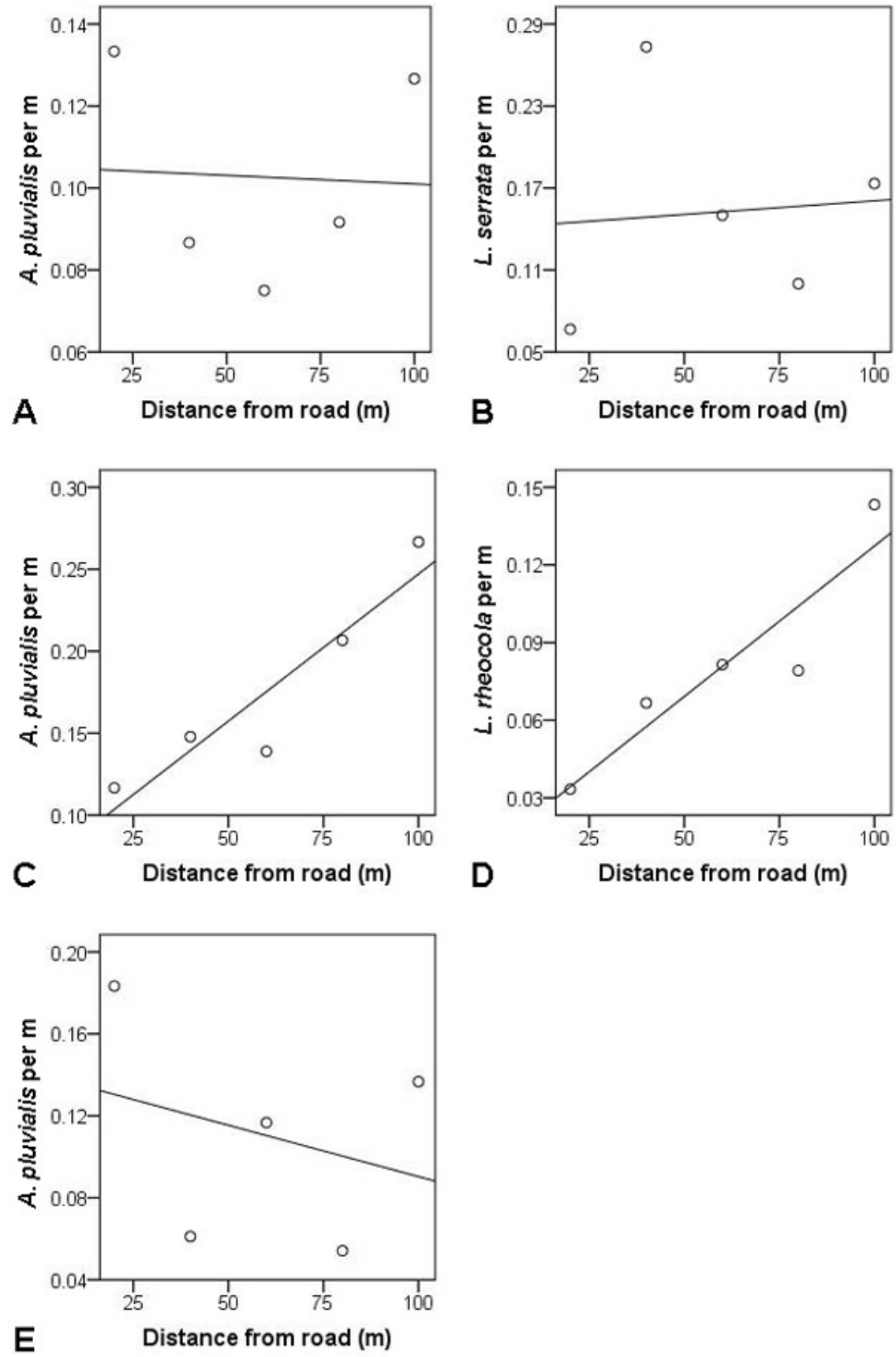
Table 2. A comparison of frog abundance on stream transects and adjacent road kill transects. Each cell shows the percentage that each frog species represents of the total number of individuals of all frog species recorded on that transect. The stream transect data was collected between January and February 2007, while the road kill data was collected between May 2005 and April 2006. The data for the two lower Avondale Creek stream transects are combined to match the single road kill transect for that area.

\begin{tabular}{lcccccccc}
\hline \hline & $\begin{array}{c}\text { lower Avondale Ck, up- \& } \\
\text { downstream }\end{array}$ & \multicolumn{2}{c}{$\begin{array}{c}\text { upper Avondale Ck, } \\
\text { upstream }\end{array}$} & Streets Ck, downstream & \multicolumn{2}{c}{ Streets Ck, upstream } \\
Species & stream \% & road \% & stream \% & road \% & stream $\%$ & road \% & stream \% & road \% \\
\hline L. serrata & 85.7 & 0 & 57.1 & 9.2 & 16.1 & 9.6 & 16.5 & 19.2 \\
L. rheocola & 0 & 0 & 0 & 0 & 0.8 & 1.1 & 34.6 & 0.6 \\
L. jungguy & 4.8 & 32.7 & 0 & 31.6 & 3.2 & 73.4 & 0.4 & 66.3 \\
L. infrafrenata & 3.2 & 22.4 & 0 & 9.2 & 0 & 1.1 & 0 & 0.6 \\
L. xanthomera & 1.6 & 44.9 & 0 & 49.0 & 0 & 9.6 & 0 & 5.8 \\
M. coggeri & 0 & 0 & 0 & 1.0 & 0.8 & 5.3 & 1.3 & 7.6 \\
A. pluvialis & 4.8 & 0 & 37.8 & 0 & 75.5 & 0 & 40.7 & 0 \\
C. ornatus & 0 & 0 & 5.1 & 0 & 3.6 & 0 & 6.5 & 0 \\
\hline
\end{tabular}

Call and body size variation within $55 \mathrm{~m}$ perpendicular distance to the road

This analysis used data from 22 L. rheocola males recorded within $55 \mathrm{~m}$ of the road, where traffic noise effects were expected to be high. Data for call traits were normally distributed, but a cube transformation was required to normalize the distance from road data. Dominant frequency exhibited a significant negative relationship with distance from $\operatorname{road}(\beta$ $\left.=-0.446, \mathrm{~F}_{1,20}=4.96, \mathrm{P}=0.038\right)$, with males closer to the road calling at higher pitch (Fig. 4A). Call rate also showed a significant negative relationship with distance from the $\operatorname{road}\left(\beta=-0.500, \mathrm{~F}_{1,19}=6.35\right.$, $\mathrm{P}=0.021)$, with males closer to the road calling more frequently (Fig. 4B). Dominant frequency and call rate were highly correlated (Pearson Correlation $=0.534, \mathrm{P}=0.001)$. Male size was also significantly related to distance from the road $\left(\beta=0.573, \mathrm{~F}_{1,19}=\right.$ 9.27, $\mathrm{P}=0.007)$, males being smaller closer to the road (Fig. 4C). No significant relationship with distance to the road was found for call duration $(\beta$ $\left.=0.372, \mathrm{~F}_{1,19}=3.06, \mathrm{P}=0.097\right)$ or pulse rate $(\beta$ $\left.=-0.278, \mathrm{~F}_{1,19}=1.59, \mathrm{P}=0.223\right)$.
Relationships between call traits and male body size

Across all L. rheocola males recorded, there was a significant negative relationship between dominant frequency and male size, i.e., SVL $(\beta=-0.322$, $\mathrm{F}_{1,36}=4.18, \mathrm{P}=0.048$ ), with smaller males having higher pitched calls. Call rate was also negatively related to male size $\left(\beta=-0.383, \mathrm{~F}_{1,34}=5.86, \mathrm{P}=\right.$ 0.021 ), with smaller males calling more frequently than larger males. The other two call traits did not show a significant relationship with male body size (duration $\beta=0.177, \mathrm{~F}_{1.34}=1.10, \mathrm{P}=0.301$; pulse rate $\left.\beta=-0.066, F_{1,34}=0.148, P=0.703\right)$.

\section{DISCUSSION}

\section{Road impacts on frog abundance}

Across the stream transects, there were five cases in which species were sufficiently common to assess abundance trends (Table 1). In three of these there was no trend in abundance versus distance from the road, whereas in the other two, i.e., A. pluvialis, downstream Streets Creek, and L. rheocola, 
Fig. 3. The relationship between (A) call rate and (B) body size, and perpendicular distance to the road for $L$. rheocola across the entire upstream Streets Creek transect. Graphs show the regression line with upper and lower $95 \%$ confidence limits. The $\mathrm{x}$-axis shows log of distance from the road; the range of the untransformed data is $15-180 \mathrm{~m}$.

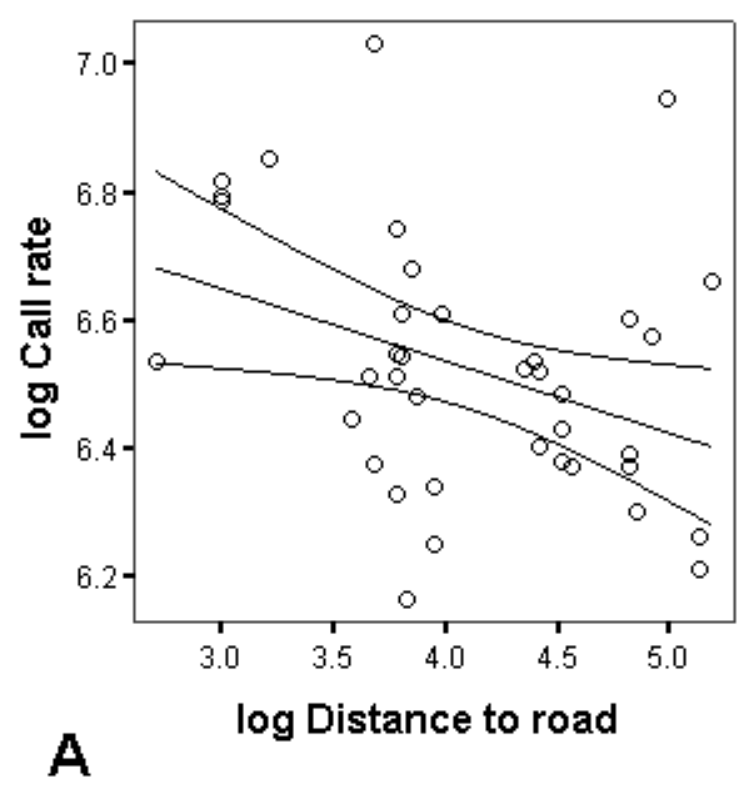

upstream Streets Creek, abundance increased with distance from the road. We do not believe these abundance trends can be explained by fine-scale variation in the distribution of breeding habitat along transects because we grouped frog count data into $20 \mathrm{~m}$ perpendicular distance groups to incorporate fine-scale habitat variability into density estimates. Additionally, habitat preference was clearly riffles for L. rheocola, and quantification of the availability of this habitat across $20 \mathrm{~m}$ groups does not explain the density trend. Therefore, lower abundance near the road most likely reflects negative road impacts, as observed for other amphibian species (Fahrig and Rytwinski 2009).

Stream pollution originating from the road and gradually dissipating downstream could affect stream-breeding species such as $L$. rheocola, but this is not the cause of the trend here because the density pattern observed was in habitat upstream from the highway. Another factor investigated was road mortality. Frogs form a large component (> $75 \%$ ) of the road kill recorded along the Kuranda

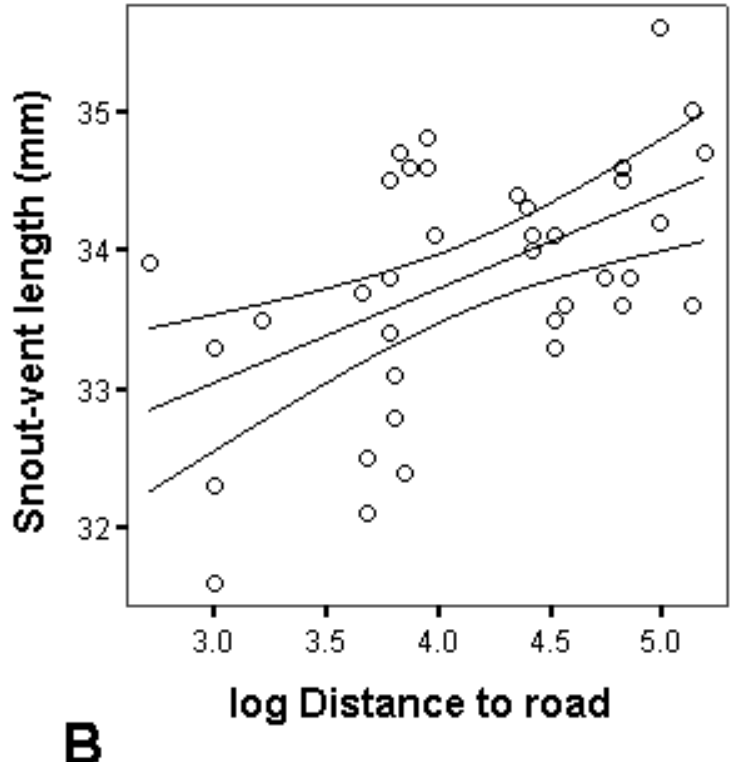

Range Road (Goosem 2000a, Goosem et al. 2006) and mortality is suspected to cause frog density depression near roads (Fahrig et al. 1995, Fahrig and Rytwinski 2009). The chance of a frog being killed should be related to how close it lives to the road, potentially producing the linear patterns detected in this study. However, both affected species are small and probably move limited distances, so density trends up to $100 \mathrm{~m}$ from the road may be too distant to ascribe to road mortality. This is supported by the fact that both affected species are either completely absent (A. pluvialis) or very rare (L. rheocola) in road mortality statistics (Table 2). In comparison, L. serrata suffers relatively high road mortality, proportional to abundance on adjacent streams (Table 2), but did not show patterns of reduced abundance near the road. One species, L. xanthomera, is of interest because it suffered very high road mortality but was very rarely recorded on the stream transects. This species is arboreal and descends following heavy rain to breed in mass aggregations around temporary roadside pools, a trait that engenders vulnerability to road kill (Laurance et al. 2009). The rarity of $L$. 
Fig. 4. The relationship between (A) dominant frequency, (B) call rate, and (C) body size, and perpendicular distance to the road for L. rheocola within $55 \mathrm{~m}$ of the road on the upstream Streets Creek transect. Graphs show the regression line with upper and lower 95\% confidence limits. The x-axis shows cubed distance to the road; the range of the untransformed data is $15-54 \mathrm{~m}$.

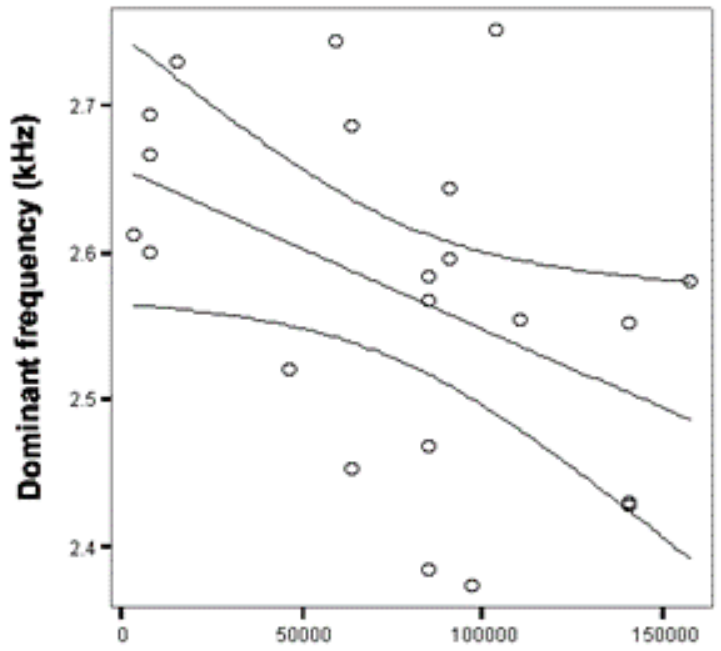

A

Distance to road (cubed)

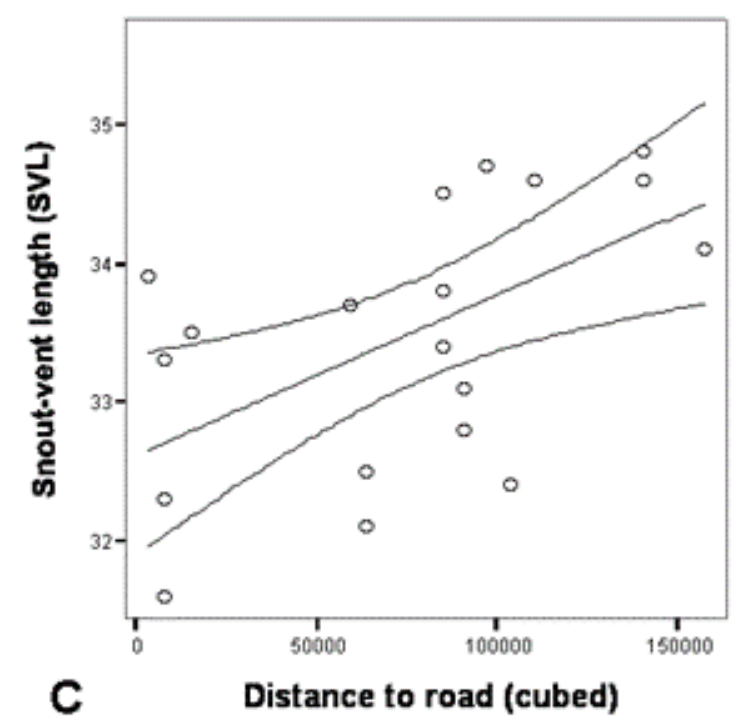

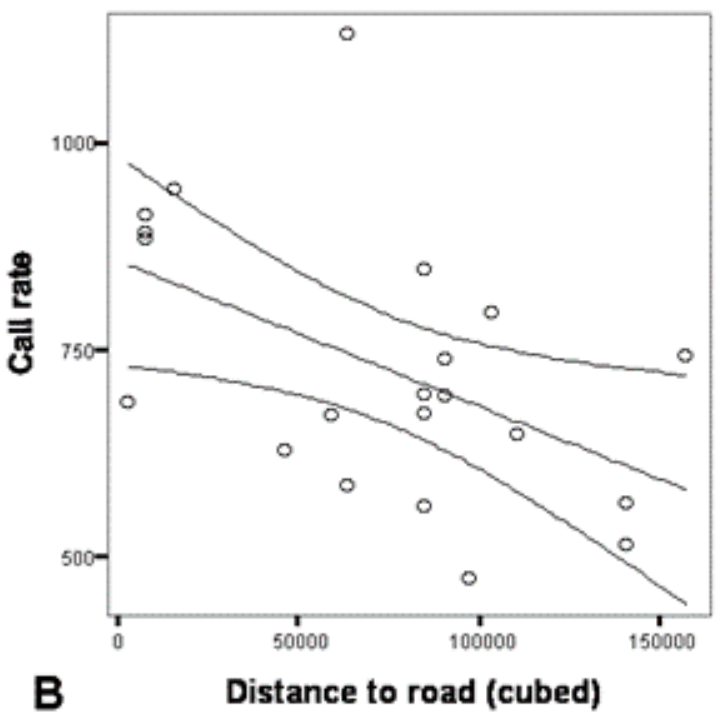

B

Distance to road (cubed) 
xanthomera on the stream transects illustrates differences in detectability between species depending on survey technique. Stream transects best detect stream-breeding species, particularly those that call vigorously, e.g., L. rheocola, but are less suitable for assessing abundance patterns of frog species with other lifestyles and breeding modes, e.g., pool-breeding species such as $L$. xanthomera.

As lower abundance of $L$. rheocola near the road does not appear to reflect road mortality, water pollution, or habitat effects, it may reflect road noise effects. Males may be avoiding breeding habitat near the road because of call masking by traffic noise. Interpretation for A. pluvialis is complicated by the lack of abundance trends relative to road proximity on the other two transects on which the species was common, and the lack of knowledge of the habitat requirements for this terrestrial-breeding species.

\section{Road impacts on call traits and body size}

Nocturnal noise levels along the stream transects were highly correlated with traffic flow, but noise levels drop off abruptly with distance from the road (M. Goosem, unpublished data). Although the noise of flowing water blankets the higher frequencies of traffic noise (M. Goosem, unpublished data), lower frequency components could still pose a problem to stream-breeding frogs calling near the road. The comparatively low frequency calls of many Australian stream-breeding frogs (Hoskin et al. 2009) may increase susceptibility to traffic noise at breeding sites. Litoria rheocola has a low frequency call (average dominant frequency $2.5 \mathrm{kHz}$ ), within the range of traffic noise masking (M. Goosem, unpublished data).

We detected significant trends in call traits and body size in L. rheocola over a very fine scale. Call rate and dominant frequency were both significantly higher closer to the road, and males were significantly smaller closer to the road. Our results fit the prediction that frogs near the road should call at higher pitch to minimize call masking by low frequency traffic noise (Slabbekoorn and Peet 2003, Slabbekoorn and Boer-Visser 2006, Parris et al. 2009). Faster call rate near the road was contrary to our prediction that call rate would be slower due to suppression of calling activity during traffic noise, but increases have been found in other studies (Sun and Narins 2005, Slabbekoorn and Boer-Visser 2006). We did not detect trends in call duration (cf. Slabbekoorn and Boer-Visser 2006) and did not measure several other traits that could be affected by traffic noise masking, such as call loudness (Brumm 2004) and call timing (Fuller et al. 2007).

We did not conduct fine-scale noise sampling along the transect so we were not able to directly correlate trends in call traits with traffic noise level. Rather we have used distance from the road as a proxy for traffic noise level (Dawe and Goosem 2008). Further research is required to test call trends directly against traffic noise levels, both on this transect and on other streams crossed by busy roads in the Wet Tropics. Although the call and body size trends we detected are most likely attributable to road impacts, resolving the exact nature of these impacts is complicated by correlations between all affected traits. Both call rate and dominant frequency are dependent on male size, and both these call traits are correlated with each other. Exactly how the road affects body size and each of the call traits remains unresolved and requires further research.

\section{Speculation}

There are several mechanisms that may potentially explain higher call frequency of male L. rheocola near the road: selection for higher call frequency, active alteration of call frequency by individuals, or spatial arrangement of individuals by body size (and hence pitch). Masking interference from background noise, e.g., traffic noise, water noise, and/or coexisting species, is expected to impose selection for increased signal contrast against the environment (Gerhardt and Huber 2002, Brumm and Slabbekoorn 2005, Hoskin et al. 2009). However, in this case, selection imposed by traffic noise would need to be very strong to generate such a strong trend in call frequency over such a small scale. Active alteration of call frequency is limited in frogs because spectral traits, e.g., dominant frequency, are determined largely by the physical dimensions of the structures involved in producing sound, hence generating the tight negative relationship between call frequency and frog size seen within and across species (Gerhardt and Huber 2002, Hoskin et al. 2009).

Spatial arrangement of individuals by body size with distance from the road could secondarily 
generate call frequency trends because of the relationship between call frequency and body size. The size of male $L$. rheocola increased with distance from the road, a pattern that could be generated by road mortality or via competition based on habitat quality. Road kill could skew body size in the observed direction because frogs living closer to the road have a greater chance of movements resulting in road mortality, resulting in potentially shorter life spans and potentially skewing the population toward younger, and therefore probably smaller (Halliday and Verrell 1988, Wells 2007) individuals near the road. However, the extreme rarity of $L$. rheocola in the highway mortality statistics suggests this is unlikely. Alternatively, road noise may generate a cline in breeding habitat quality, with habitat quality increasing away from the road due to reduction in noise effects. This may generate competition between males, and if competition is mediated by size, as is generally the case in frogs (Wells 2007), a cline in body size and correlated call traits may result.

Litoria rheocola called at a faster rate closer to the road, so traffic noise did not appear to be suppressing calling activity. Sun and Narins (2005) found that traffic noise (airplane and motorcycle) had variable effects on call rate in a chorus of frogs in Thailand. Although three species showed slight decreases in call rate during playbacks of traffic noise, one species increased call rate. The authors suggested that traffic noise suppressed calling activity (rate) in the three species, and this lull in the frog chorus initiated one species (with a call frequency higher than likely to be affected by traffic noise) to increase call rate. The call frequency of $L$. rheocola is within the frequency range likely to be affected by traffic noise so the call rate trend is more likely to represent direct effects from traffic noise than a secondary response to effects of traffic noise on the calling behavior of co-occurring species. A possible reason for increased call rate near the road is that these males are compensating for calls masked by traffic noise. For dominant frequency, interpretations are complicated by the fact that call rate in our data is dependent on body size. Further, call rate and dominant frequency are correlated.

\section{CONCLUSIONS}

We detected trends in abundance and calling behavior of frogs relative to distance from a busy road. These trends along the streams occurred over a scale affected by nocturnal traffic noise, and were generally in the direction predicted for road impacts. Abundance was lower near the road in two species, but not in several other cases, and road mortality was not implicated as a causal factor because the two species are extremely rare in road kill statistics. Males of the endangered species Litoria rheocola near the road are smaller and utter calls more frequently and at higher pitch than those further from the road. Interpretation of these trends is complicated by correlations between these traits, illustrating the complex links between phenotypic traits and the importance of measuring multiple traits in such studies. We conclude that traffic noise is most likely driving these trends, but further research is required along these and other streams to directly link patterns with road impacts such as traffic noise. Although road impacts may appear localized in protected areas such as the WTWHA, they may pose a significant threat to localized populations or species already threatened by other factors.

\section{Mitigating and monitoring the effects of roads on frogs}

The trends detected in this study occurred over a very small scale; whereas other road impacts on stream-breeding frogs in this area, e.g., changes to water flow, water quality, and sedimentation associated with road construction and run-off (Hoskin 2007), may extend over considerably greater distances from the road. Potential ways to mitigate the effects of roads on frogs include: avoiding construction of stream crossings near known breeding sites for threatened species; using high bridges at stream crossings to enable frogs to move along the stream below the road, and to reduce noise effects on the streams; using concrete barriers to reduce noise effects at creek crossings; limiting disturbance to streambed structure and associated banks and vegetation during construction; and controlling impacts to water flow, water quality, and sedimentation associated with run-off from roads.

This study illustrates the difficulties in detecting and explaining causes of the road effect zone (see also Bissonette and Rosa 2009), even when potential factors such as microhabitat variability and vehicle mortality can be examined and largely eliminated. In one species, $A$. pluvialis, there was variability in apparent road impact on abundance, suggesting that landscape may affect road impacts, whereas in the 
other affected species, L. rheocola, road impact on calling behaviour is complicated by correlations between traits. For environmental impact assessment and decision making, preservation of undisturbed habitat remains the safer option over attempts at mitigation.

Responses to this article can be read online at: http://www.ecologyandsociety.org/vol15/iss3/art15/ responses/

\section{Acknowledgments:}

This project was jointly funded by the Queensland Department of Main Roads and the Australian Government's Marine and Tropical Science Research Facility (through the Reef and Rainforest Research Centre). We thank Gregory Dawe (James Cook University) for assistance with traffic noise information, and Les Searle (James Cook University) for map creation. We also thank Allan Armstrong (QDMR), David Rivett (Environment North), Megan Higgie (The Australian National University), Keith McDonald (Queensland Parks and Wildlife Service), Craig Moritz (University of California, Berkeley), a number of volunteers for assistance with fieldwork, and three anonymous reviewers for comments that improved the manuscript.

\section{LITERATURE CITED}

Bee, M. A., and E. M. Swanson. 2007. Auditory masking of anuran advertisement calls by road traffic noise. Animal Behaviour 74:1765-1776.

Berger, L., R. Speare, P. Daszak, D. E. Green, A. A. Cunningham, C. L. Goggin, R. Slocombe, M. A. Ragan, A. D. Hyatt, K. R. McDonald, H. B. Hines, K. R. Lips, G. Marantelli, and H. Parkes. 1998. Chytridiomycosis causes amphibian mortality associated with population declines in the rainforests of Australia and Central America. Proceedings of the National Academy of Sciences USA 95:9031-9036.
Bissonette, J. A., and S. A. Rosa. 2009. Road zone effects in small-mammal communities. Ecology and Society 14: 27. [online] URL: http://www.ecol ogyandsociety.org/vol14/iss1/art27/.

Brumm, H. 2004. The impact of environmental noise on song amplitude in a territorial bird. Journal of Animal Ecology 73:434-440.

Brumm, H. 2006. City birds have changed their tune. Current Biology 16:R1003-R1004.

Brumm, H., and H. Slabbekoorn. 2005. Acoustic communication in noise. Advances in the Study of Behavior 35:151-209.

Dawe, G., and M. Goosem. 2008. Noise disturbance along highways: Kuranda Range Road upgrade project. Report to the Marine and Tropical Sciences Research Facility. Reef and Rainforest Research Centre Limited, Cairns, Australia. [online] URL: http://www.rrrc.org.au/publications/ downloads/Transition-JCU-Dawe-et-al-2008-Noisedisturbance-along-highways.pdf.

Eigenbrod, F., S. J. Hecnar, and L. Fahrig. 2008. The relative effects of road traffic and forest cover on anuran populations. Biological Conservation 141:35-46.

Eigenbrod, F., S. J. Hecnar, and L. Fahrig. 2009. Quantifying the road-effect zone: threshold effects of a motorway on anuran populations in Ontario, Canada. Ecology and Society 14: 24. [online] URL: http://www.ecologyandsociety.org/vol14/iss 1/art24/

Fahrig, L., J. Pedlar, S. Pope, P. Taylor, and J. Wegner. 1995. Effect of road traffic on amphibian density. Biological Conservation 11:1000-1009.

Fahrig, L., and T. Rytwinski. 2009. Effects of roads on animal abundance: an empirical review and synthesis. Ecology and Society 14: 21. [online] URL: http://www.ecologyandsociety.org/vol14/iss1/ $\underline{\operatorname{art} 21 /}$.

Forman, R. T. T., D. Sperling, J. A. Bissonette, A. P. Clevenger, C. D. Cutshall, V. H. Dale, L. Fahrig, R. France, C. R. Goldman, K. Heanue, J. A. Jones, F. J. Swanson, T. Turrentine, and T. 
C. Winter. 2003. Road ecology: science and solutions. Island Press, Washington D.C., USA.

Fuller, R. A., P. H. Warren, and K. J. Gaston. 2007. Daytime noise predicts nocturnal singing in urban robins. Biology Letters 3:368-370.

Gerhardt, H. C., and F. Huber. 2002. Acoustic communication in insects and anurans. University of Chicago Press, Chicago, Illinois, USA.

Goosem, M. 2000a. Impacts of roads and powerline clearings on rainforest vertebrates with emphasis on ground-dwelling small mammals. Dissertation. James Cook University, Cairns, Australia.

Goosem, M. 2000b. Effects of tropical rainforest roads on small mammals: edge changes in community composition. Wildlife Research 27:151-163.

Goosem, M. 2001. Effects of tropical rainforest roads on small mammals: inhibition of crossing movements. Wildlife Research 28:351-364.

Goosem, M. 2007. Fragmentation impacts caused by roads through rainforests. Current Science 93:1587-1595.

Goosem, M., N. Weston, and S. Bushnell. 2006. Effectiveness of rope bridge arboreal overpasses and faunal underpasses in providing connectivity for rainforest fauna. Pages 304-316 in C. L. Irwin, P. Garrett, and K. P. McDermott, editors. Proceedings of the 2005 International Conference on Ecology and Transportation. Center for Transportation and Environment, North Carolina State University, Raleigh, North Carolina, USA. [online] URL: http://repositories.cdlib.org/jmie/roadeco/ Goosem2005a/.

Halliday, T. R., and P. A. Verrell. 1988. Body size and age in amphibians and reptiles. Journal of Herpetology 22:244-246.

Hoskin, C. J. 2004. Australian microhylid frogs (Cophixalus and Austrochaperina): phylogeny, taxonomy, calls, distributions and breeding biology. Australian Journal of Zoology 52:237-269.

Hoskin, C. J. 2007. Description, biology and conservation of a new species of Australian tree frog (Anura: Hylidae: Litoria) and an assessment of the remaining populations of Litoria genimaculata
Horst, 1883: systematic and conservation implications of an unusual speciation event. Biological Journal of the Linnean Society 91:549-563.

Hoskin C. J., and J. M. Hero. 2008. Rainforest frogs of the wet tropics, north-east Australia. Griffith University, Gold Coast, Australia.

Hoskin, C. J., M. Higgie, K. R. McDonald, and C. Moritz. 2005. Reinforcement drives rapid allopatric speciation. Nature 437:1353-1356.

Hoskin, C. J., S. James, and G. C. Grigg. 2009. Ecology and taxonomy-driven deviations in the frog call-body size relationship across the diverse Australian frog fauna. Journal of Zoology (London) 278:36-41.

Kofron, C. P., and A. Chapman. 2006. Causes of mortality to the endangered Southern Cassowary Casuarius casuarius johnsonii in Queensland, Australia. Pacific Conservation Biology 12:175-179.

Laurance, W. F., B. M. Croes, N. Guissouegou, R. Buij, M. Dethier, and A. Alonso. 2008. Impacts of roads, hunting, and habitat alteration on nocturnal mammals in African rainforests. Conservation Biology 22:721-732.

Laurance, W. F., M. Goosem, and S. G. Laurance. 2009. Impacts of roads and linear clearings on tropical ecosystems. Trends in Ecology and Evolution 24:659-669.

Parris, K. M. 2006. Urban amphibian assemblages as metacommunities. Journal of Animal Ecology 36:812-824.

Parris, K. M. and A. Schneider. 2009. Impacts of traffic noise and traffic volume on birds in roadside habitats. Ecology and Society 14: 29. [online] URL: http://www.ecologyandsociety.org/vol14/iss1/art29/

Parris, K. M., M. Velik-Lord, and J. M. A. North. 2009. Frogs call at a higher pitch in traffic noise. Ecology and Society 14: 25. [online] URL: http://w ww.ecologyandsociety.org/vol14/iss1/art25/.

Pellet, J., A. Guisan, and N. Perrin. 2004a. A concentric analysis of the impact of urbanization on the threatened European tree frog in an agricultural landscape. Conservation Biology 18:1599-1606. 
Pellet, J., S. Hoehn, and N. Perrin. $2004 b$. Multiscale determinants of tree frog (Hyla arborea L.) calling ponds in western Switzerland. Biodiversity and Conservation 13:2227-2235.

Richards, S. J., C. J. Hoskin, M. J. Cunningham, K. McDonald, and S. C. Donnellan. 2010. Taxonomic reassessment of the Australian and New Guinean green-eyed treefrogs Litoria eucnemis, $L$. genimaculata and L. serrata (Anura: Hylidae). Zootaxa 2391:33-46.

Richards, S. J., K. R. McDonald, and R. A. Alford. 1993. Declines in populations of Australia's endemic tropical rainforest frogs. Pacific Conservation Biology 1:66-77.

Slabbekoorn, H., and A. den Boer-Visser. 2006. Cities change the songs of birds. Current Biology 16:2326-2331.

Slabbekoorn, H., and M. Peet. 2003. Birds sing at a higher pitch in urban noise. Nature 424:267.

Sun, J. W .C., and P. M. Narins. 2005. Anthropogenic sounds differentially affect amphibian call rate. Biological Conservation 121:419-427.

Trenham, P. C., W. D. Koenig, M. J. Mossman, S. L. Stark, and L. A. Jagger. 2003. Regional dynamics of wetland-breeding frogs and toads: turnover and synchrony. Ecological Applications 13:1522-1532.

Warren, P. S., M. Katti, M. Ermann, and A. Brazel.2006. Urban bioacoustics: it's not just noise. Animal Behaviour 71:491-502.

Wells, K. D. 2007. The ecology and behavior of amphibians. University of Chicago Press, Chicago, Illinois, USA.

Wilson, R. F., H. Marsh, and J. Winter. 2007. Importance of canopy connectivity for home range and movements of the rainforest arboreal ringtail possum (Hemibelideus lemuroides). Wildlife Research 34:177-184. 
APPENDIX 1. Stream transect details. Elevation refers to average elevation above sea level (a.s.1.).

\begin{tabular}{|c|c|c|c|c|c|}
\hline Transect name & $\begin{array}{l}\text { lower Avondale Ck } \\
\text { Downstream }\end{array}$ & $\begin{array}{l}\text { lower Avondale Ck } \\
\text { Upstream }\end{array}$ & $\begin{array}{l}\text { upper Avondale Ck } \\
\text { Upstream }\end{array}$ & $\begin{array}{l}\text { Streets Ck } \\
\text { Downstream }\end{array}$ & $\begin{array}{l}\text { Streets Ck } \\
\text { Upstream }\end{array}$ \\
\hline Length (m) & $200 \mathrm{~m}$ & $200 \mathrm{~m}$ & $125 \mathrm{~m}$ & $200 \mathrm{~m}$ & $325 \mathrm{~m}$ \\
\hline Elevation (m) & $120 \mathrm{~m}$ a.s.l. & $140 \mathrm{~m}$ a.s.l. & $350 \mathrm{~m}$ a.s.l. & $360 \mathrm{~m}$ a.s.l. & $350 \mathrm{~m}$ a.s.l. \\
\hline Start latitude & $16^{\circ} 50^{\prime} 37.56^{\prime \prime}$ & $16^{\circ} 50^{\prime} 37.68^{\prime \prime}$ & $16^{\circ} 50^{\prime} 44.28^{\prime \prime}$ & $16^{\circ} 49^{\prime} 39.42^{\prime \prime}$ & $16^{\circ} 49^{\prime} 36.54^{\prime \prime}$ \\
\hline $\begin{array}{l}\text { Start } \\
\text { longitude }\end{array}$ & $145^{\circ} 40^{\prime} 48.00^{\prime \prime}$ & $145^{\circ} 40^{\prime} 46.98^{\prime \prime}$ & $145^{\circ} 40^{\prime} 22.32^{\prime \prime}$ & $145^{\circ} 39^{\prime} 15.12^{\prime \prime}$ & $145^{\circ} 39^{\prime} 15.78^{\prime \prime}$ \\
\hline Finish latitude & $16^{\circ} 50^{\prime} 35.04^{\prime \prime}$ & $16^{\circ} 50^{\prime} 37.62^{\prime \prime}$ & $16^{\circ} 50^{\prime} 47.04^{\prime \prime}$ & $16^{\circ} 49^{\prime} 39.96^{\prime \prime}$ & $16^{\circ} 49^{\prime} 32.52^{\prime \prime}$ \\
\hline $\begin{array}{l}\text { Finish } \\
\text { longitude }\end{array}$ & $145^{\circ} 40^{\prime} 52.68^{\prime \prime}$ & $145^{\circ} 40^{\prime} 40.80^{\prime \prime}$ & $145^{\circ} 40^{\prime} 19.62^{\prime \prime}$ & $145^{\circ} 39^{\prime} 11.82^{\prime \prime}$ & $145^{\circ} 39^{\prime} 22.74^{\prime \prime}$ \\
\hline
\end{tabular}

